\title{
Taxonomic studies of Myrcia (Myrciinae, Myrtaceae) in Brazil: morphological novelties, circumscriptions, and new records for the Amazon'
}

\author{
Alessandro S. do Rosário², José Fernando A. Baumgratz ${ }^{3}$ \& Ricardo de S. Secco ${ }^{4}$ \\ Part of the PhD thesis of the first author in the Postgraduate Program in Botany, Escola Nacional de Botânica Tropical, \\ Instituto de Pesquisas Jardim Botânico do Rio de Janeiro \\ ${ }^{2}$ Universidade do Estado do Pará, Centro de Ciências Naturais e Tecnologia, PPGCA/PNPD/CAPES, Trav. Dr. Enéas Pinheiro 2626, Marco, \\ CEP 66.095-10, Belém, Pará, Brazil. asrosario florestal@hotmail.com.br \\ 3 Instituto de Pesquisas Jardim Botânico do Rio de Janeiro, Rua Pacheco Leão 915, CEP 22.460-030, Jardim Botânico, \\ Rio de Janeiro, Brazil. jbaumgra@jbrj.gov.br \\ ${ }^{4}$ Museu Paraense Emílio Goeldi, Coordenação de Botânica, Av. Magalhães Barata 376, CEP 66.040-170, Belém, PA, Brazil. \\ rsecco@museu-goeldi.br
}

Recebido 19.V.2015.

Aceito em 25.VI.2017

DOI $10.21826 / 2446-8231201772203$

\begin{abstract}
Based on recent studies on Myrtaceae in the Brazilian Amazon, we present an update of the morphological circumscription of Myrcia, including eight new occurrences of the genus in Pará State, three of which represent new records for the Amazon region. Comments are provided on the diagnostic features and taxonomic affinities of each species, their geographic distributions, and their preferred environments of occurrence. Recommendations for updating the list of Brazilian Myrtaceae species are presented.
\end{abstract}

Keywords: Brazilian Amazon, geographic distribution, taxonomy

RESUMO - Estudos taxonômicos em Myrcia (Myrciinae; Myrtaceae) no Brasil: novidades morfológicas, circunscrição e novas ocorrências para a Amazônia. Baseado em recentes estudos em Myrtaceae para a Amazônia brasileira, apresenta-se uma atualização da circunscrição morfológica de Myrcia e oito novos registros de ocorrência do gênero no estado do Pará, dos quais três também representam novas ocorrências para a Amazônia brasileira. Comentários sobre características diagnósticas e afinidades taxonômicas de cada espécie, bem como os respectivos dados de distribuição geográfica e ambientes preferenciais de ocorrência são fornecidos. Recomendações para atualização da lista de espécies de Myrtaceae da flora do Brasil também são apresentadas.

Palavras-chave: Amazônia brasileira, distribuição geográfica, taxonomia

\section{INTRODUCTION}

Myrtaceae has traditionally been divided into two tribes: Leptospermeae, with capsular fruits and exclusively paleotropical distribution; and Myrteae, with fleshy fruits and most species occurring in South America. Myrteae comprises three subtribes: Myrciinae, Eugeniinae, and Myrtinae (Lucas et al. 2005, 2011). A new classification for Myrtaceae, however, proposes two subfamilies (Psiloxyloideae and Myrtoideae) and 17 tribes (Wilson et al. 2005, 2011). According to Lucas et al. (2007), the genus Myrcia belongs to the tribe Myrteae, which is expressive in Brazil, and currently unites eight informal groups, two of which have uncertain positions in the phylogeny of that group. Also according to these authors, the 'Myrcia group' covers all taxa previously included in the subtribe Myrciinae and the genus Mitranthes O. Berg.

The subtribe Myrciinae is represented in Brazil by three genera and 373 species, of which 289 are endemic; there are three genera and ca. 90 species in the Amazon biome (Sobral et al. 2012). This represents a very complex plant grouping from a taxonomic point of view, especially in terms of the generic delimitations. According to Rosário (2012) and Sobral et al. (2012), the genera of this subtribe have high numbers of species in the Brazilian Amazon (except Gomidesia O. Berg), with Calyptranthes Sw., (ca. 26 spp.), Marlierea Cambess. (ca. 13 spp.), and Myrcia DC. (ca. 52 spp.).

According to McVaugh (1958), and Rosário et al. (2014a, 2014b), Calyptranthes and Marlierea are well known in South America, and distinguishable primarily by a dehiscent calyx and the exposure of the corolla in the floral bud (pre-anthesis): dehiscent calyx and exposed corolla in Myrcia and Gomidesia; and indehiscent calyx and enclosed corolla in Calyptranthes and Marlierea.

Several studies have highlighted taxonomic and floristic controversies in recognizing Calyptranthes, Gomidesia, Marlierea, and Myrcia as distinct taxa. Studies have 
generally pointed to the dehiscent calyx (and the resulting exposure of the corolla in the floral bud - mistakenly considered for many years as "closed bud" $\mathrm{x}$ "open bud"), the formation or not of distinct sepals, as well as the shape of the hypanthium apex, the persistent calyx, and/or anther dehiscence as the most valuable diagnostic features (McVaugh 1958, 1969; Legrand \& Klein 1969; Barroso et al. 1984; Kawasaki 1989; Nic Lughadha 1995; Holst et al. 2003; Sobral 2003; Souza et al. 2007).

Myrcia has Neotropical distribution and is uniquely American (McVaugh 1969). This author also mentions that the number of species in the genus is uncertain, but is believed to be more than 300 , of which ca. $66 \%$ occur in Brazil. Sobral et al. (2012) determined that Myrcia is represented by 243 species in Brazil, with 52 in the Brazilian Amazon and 28 found in Pará State.

Recent taxonomic studies of Myrciinae have indicated new morphological features that extend the circumscriptions of its genera, new synonyms, and new records for the Brazilian flora and the Amazon region, as well as for the states of Amazonas and Pará (Rosário 2012). Continuing these studies, the present work provides additional data for the morphological circumscription of Myrcia, and described eight new occurrences for Pará State - three of which are also new for the Brazilian Amazon, and one for Brazil. Comments are made concerning circumscriptions, taxonomic affinities, and information concerning their geographic distributions and the vegetation formations where the species are found in Brazil is provided. It is worth noting that the identifications of eight new Myrcia records argue for updating the list of Myrtaceae species of Brazilian floras (Sobral et al. 2012).

\section{MATERIALS AND METHODS}

The surveys of herbarium collections principally considered herbaria in northern Brazil (EAFM, IAN, INPA, MG), as well as the collections of R, RB, BHCB and UB and photographic reproductions of the nomenclatural types of Myrciinae deposited in the BM, BR, F, K, $\mathrm{MICH}, \mathrm{M}$, $\mathrm{MO}, \mathrm{NY}, \mathrm{P}, \mathrm{US}$ and $\mathrm{U}$ herbaria (acronyms according to Thiers 2012). The abbreviations of the authors' names and the genera and species follow Brummitt \& Powell (1992). Species identifications were performed with the aid of the specialized literature (Amshoff 1948; Holst et al. 2003; Souza et al. 1999; McVaugh 1958, 1969; Rosário et al. 2005, 2014a, 2014b; Rosário \& Secco 2006, 2013), using material identified by experts, type specimens, photographs and/or scanned images, as well as consultations with Myrtaceae specialists. We analyzed material from the study areas and, when necessary, additional collections were consulted. Illustrations were made, and phenological data, geographic distributions, and taxonomic affinities were cited and comments on distributions in Brazilian phytophysiognomies are provided. Morphological analyses and laboratory measurements were performed with the aid of a CARL ZEISS ${ }^{\circledR}$ stereoscopic microscope. The morphological characterizations used the concepts of McVaugh (1956, 1968, 1969), Radford et al. (1974), and Barroso et al. (1999). The characterizations of the phytophysiognomies were based on the vegetation classification proposed by Pires \& Prance (1985). Information concerning the flowering periods (buds in pre-anthesis, and fully open) and fruiting (ovaries starting to develop, and ripe fruits ready for dispersal) of the species was gathered from the literature and from herbarium labels.

\section{RESULTS AND DISCUSSION}

\section{Myrcia DC., Dict. Class. Hist. Nat. 11: 378, 401, 406. 1827. [emend. A. Rosário \& Baumgratz]}

Trees or shrubs, rarely lianas. Inflorescences in panicles or reduced to panicles of racemes (racemiform) or panicles of fascicles (fasciculiform), rarely panicles of dichasia, unifloral or in pairs, or multiflorous, rarely pauciflorous; bracts and bracteoles deciduous or persistent after anthesis. Flowers sessile or pedicellate; hypanthium extended ca. $1 \mathrm{~mm}$ beyond the ovary apex, or reduced; calyx usually with valvate pre-flowering, sometimes quincuncial, (4-)5-merous, regular sepals, free; corolla (4-)5-merous, regular petals, free; disk zone glabrous or pilose; ovary 2(-3)-locular, (1-)2 ovules per locule, glabrous or pilose at apex; placentation axillary. Fruit bacciferous, 1-2(-3) seeds, with calyx and staminal disk often persistent; myrcioid embryos.

Myrtaceae experts have used the expressions "open bud or closed bud" for many years to characterize the floral buds in Myrcia, these being viewed as distinctive and practical characters for the systematics of Myrciinae - "open buds" being associated with Myrcia and "closed buds" with Calyptranthes and Marlierea. However, this characterization was not adopted in the present study, as we followed the proposal of Rosário (2012), who described the morphologies of the floral buds of Myrciinae based primarily on calyx dehiscence. This author, and Rosário et al. (2014a, 2014b), concluded that these features are the most diagnostic for distinguishing between Calyptranthes, Marlierea, and Myrcia and, in practice, very useful in the systematics of Amazonian species. It is noteworthy, on the other hand, that, disregarding these characteristics of the calyx and accepting that these taxa constitute a single monophyletic generic entity (as has been suggested by Lucas et al. 2007, 2011), all the species belonging to these genera should be subordinated to Calyptranthes by the rule of priority, as was pointed out by Rosário et al. (2014b). Thus, given these recent studies of the Amazonian Myrciinae, two basic morphological patterns of the calyx and corolla during anthesis can be recognized: (1) together, they constitute a fused floral entity covering the androecium and gynoecium (without distinction between the calyx and corolla), with the dehiscence of these structures occurring simultaneously (in Calyptranthes and Marlierea); in this situation, the dehiscence of the calyx serves to distinguish these two 
taxa from each other, with the calyx in Calyptranthes being circumcised and forming a calyptra, caducous or not, while in Marlierea being partially or totally irregular, forming sepals of irregular sizes and shapes; (2) Myrcia shows a clear distinction between the calyx and corolla during the anthesis, and the dehiscence of these two structures do not occur simultaneously, with dehiscence of the corolla initiating after the calyx is fully open; in this situation, the pre-flowering of the calyx is valvate or quincuncial, forming regular sepals, rarely irregular.

This study, and the work of Rosário (2012), which covers the Amazon region, provides new morphological data that will expand our knowledge of the morphology of the genus Myrcia and, therefore, its circumscription. In this context, the lianescent habit of M. huallagae (a species restricted to the Amazon Biome) and flowers with calyx of valvate or quincuncial pre-flowering, with sepals regular in shape and size, rarely irregular, are incorporated into the Myrcia circumscription, as well as that of the Myrtaceae of Brazil. Equally, it highlights the importance of regional floras, particularly of the Amazon Biome that analyze several herbarium collections to more precisely define the taxonomy of the species occurring in Brazil thus complementing and updating the circumscriptions of complex genera such as Calyptranthes, Marlierea, and Myrcia, and the systematics of the family.

According to Sobral et al. (2012), Myrcia is represented by 28 species in Pará State, although Rosário (2012) recognized 31 species - of which Myrcia huallagae McVaugh, Myrcia laruotteana Cambess., Myrcia mansoniana O.Berg, Myrcia ovata Cambess., Myrcia albidotomentosa (Amshoff) McVaugh, Myrcia amapensis McVaugh, Myrcia clusiifolia (Kunth) DC., Myrcia revolutifolia McVaugh, and Myrcia saxatilis (Amshoff) McVaugh are addressed in this work in different taxonomic and biogeographic contexts.

\section{Novelty for the morphological circumscription of Myrtaceae in Brazil}

Myrcia huallagae McVaugh, Fieldiana, Bot. 29(3): 192. 1956.

(Figs. $1 \mathrm{~A}-\mathrm{C})$

According to Sobral et al. (2012) and Rosário (2012), Myrcia huallagae McVaugh is endemic to the Amazon region, occurring in Peru and being widely distributed in Brazil (in the states of Pará, Amazonas, Acre, Rondônia). It is found in capoeira forests (secondary upland vegetation). In Pará, this taxon is represented by only a single collection.

Myrcia huallagae is similar to Myrcia bracteata (Rich.) DC., but is distinguished by being a liana, with trichomes 3-4 mm long on the branches, and subsessile leaves (vs. shrubs to trees, with trichomes on the branches $0.5-2 \mathrm{~mm}$ long, and distinctly petiolate leaves in $M$. bracteata). Thus, the lianescent habit appears exclusively in this taxon in the Amazon. Importantly, McVaugh (1956) mentioned the lianescent habit in the original work on M. huallagae for Peru, which reinforces the inclusion of this feature in the circumscription of Myrcia, as well as in the Brazilian Myrtaceae. This new feature completes information about the family in lists of the Brazilian flora (Sobral et al. 2012). This species is popularly known in the Amazon region as "murta cabeluda" (hairy myrtle, in Portuguese).

Specimens examined: BRAZIL. PARÁ: Benfica, 24.X.2006, bot., fl., D. Mitja \& D.C. Carvalho 10123 (MG).

\section{New records for the Brazilian Amazon}

Myrcia laruotteana Cambess., Fl. Bras. Merid. 2: 311. 1832.

$$
\text { (Figs } 1 \text { D-F) }
$$

This species is recorded here for the first time in the Brazilian Amazon, as well as for the first time in Pará State, where it occurs in terra firme (primary and secondary upland) and várzeas (floodplain) forests. The leaves are strongly chartaceous, with conspicuous venation, with pubescent trichomes restricted to the midrib - diagnostic characters distinguishing it from other Myrcia taxa from the Amazon region. It is noteworthy that the subsessile leaves, as well as the albescent-tomentose bracts isolated or forming a rosette at the base of the inflorescence rachis and common in specimens from the Brazilian Cerrado (tropical savanna), were not observed in the Amazon collections. Species from southern and southeastern Brazil, in the Atlantic Forest biome, are likewise devoid of these morphological characters.

Thus, considering the wide distribution of $M$. laruotteana in Brazil (in the states of Pará, Tocantins, Maranhão, Mato Grosso, Goiás, Distrito Federal, Mato Grosso do Sul, Minas Gerais, Espírito Santo, São Paulo, Paraná, and Santa Catarina), preferentially in terra firme and várzea forests, it can be inferred that their observed morphological variations may be associated with the different environments in which the individuals occur, characterizing them as plastic vegetative structures. Myrcia laruotteana is popularly known in the Amazon as myrtle and "goiabinha-casca-lisa" (small guava with a smooth skin, in Portuguese).

Specimens examined: BRAZIL. PARÁ: Parauapebas, Serra dos Carajás, FLONA, 18.VII.1990, bot., N.A. Rosa 5285 (MG); Gurupi River, 6.I.1910, bot., F. Lima s.n. (MG 10752); Peixe-Boi, Monte Verde Farm, $01^{\circ} 11^{\prime}$ 'S, 47¹9’W, 11.III.1991, fr., R.P. Salomão et al. 775 (MG); Oriximiná, Trombetas River, Mineração Rio do Norte, XII.1999, fl., fr., M.F. Quintela s.n. (MG 159950). MATO GROSSO: Luciara, Distrito de Porto Alegre, $11^{\circ} 10^{\prime}$ S, 51ํํ’W, 16.X.1985, fl., J. Pirani 1294 (MG).

Myrcia mansoniana O. Berg, Fl. Bras. 14(1): 163. 1857.

$$
\text { (Figs. } 1 \mathrm{G}, \mathrm{H} \text { ) }
$$


This species is recorded here for the first time in the Brazilian Amazon, occurring only in Pará State and restricted to the Serra do Cachimbo where it occurs in terra firme (primary upland) forests and in submontane areas with rocky outcrops (Rosário 2012). According to Sobral et al. (2012), this species is endemic to Brazil (Mato Grosso and Goiás States), with its center of distribution in the Cerrado biome. Thus, the species appears to have a disjunct distribution in two biomes with ecological conditions that favor its development (Rosário 2012). Myrcia mansoniana is similar to M. mollis (Kunth) DC., which can be primarily recognized by their velutinous vegetative and reproductive structures. However, M. mansoniana can be distinguished by having velutinous petioles on the young branches, and rusty trichomes on the peduncle, disc zone, and fruits (vs. sericeous-pubescent indument, with albescent to golden trichomes in M. mollis). Despite not having been able to analyze material with buds and flowers, we infer that the pre-flowering is of the quincuncial type, as the sepals on the fruits partially overlap each other.

Specimens examined: BRAZIL. PARÁ: Itaituba, Serra do Cachimbo, Cachoeira de Curuá, north of the mountain slope, 05.XI.1977, fr., G.T. Prance et al. 24882 (MG).

Myrcia ovata Cambess., Fl. Bras. Merid. 2: 319. 1832.

(Figs. 1 I, J)

According to Sobral et al. (2012), this species is endemic to the Atlantic Forest (in the states of Espírito Santo, São Paulo, and Rio de Janeiro), although it is cited here for the first time from Pará State and the Brazilian Amazon. It is found there as a subshrub to shrub in restinga environments (sandy coastal shrubby vegetation) and bordering secondary vegetation. Myrcia ovata distinguishes itself from other species of the genus by its subshrub or shrubby habit, distinctly oval leaves, glabrous, with marginal rib 2-4 $\mathrm{mm}$ distant from the margin, short petioles, canaliculated and glabrous flowers, with short pedicels (ca. $1 \mathrm{~mm}$ long). Rosário (2012) noted that many of the M. ovata collections deposited in the RB herbarium come from restinga environments in Rio de Janeiro State, which suggests that this is its preferred environment, although it is now known to have a disjunct distribution between the Amazon and Atlantic Forest biomes, indicating the states of Pará and Rio de Janeiro as distribution centers in their respective regions.

Specimens examined: BRAZIL. PARÁ: Tucuruí, BR263, 0330'S, 49³2'W, 28.X.1981, fl., D.C. Daly et al. 975 (INPA, MG, NY); Maracanã, Ilha de Fortalezinha, XII.1999, fl., L.C.B. Lobato et al. 2473 (MG); ibid. loc., XII.1999, fl., A.S. Rosário \& L.C.B. Lobato 01 (MG); Maracanã, Maiandeua, near the hole of Cambuinha, 20.IX.2007, fl., A.S. Rosário et al. 34 (MG); Maracanã, Maiandeua, near the hole of Cambuinha, 20.IX.2007, fr., A.S. Rosário et al. 35 (MG); Tomé-Açu, 1,500 m away from the Curiman Farm, 05.I.1978, bot., O.C. Nascimento
423 (INPA, MG, NY); Moju, Maiza Farm, 03.VIII.1994, bot., I.A. Rodrigues 1616 (IAN).

\section{New records for the state of Pará}

Myrcia albidotomentosa (Amshoff) Mc Vaugh, Mem. New York Bot. Gard. 18(2): 79. 1969.

(Figs. 2 A, B)

This species is recorded here for the first time for Pará State. According to Holst et al. (2003), this taxon occurs in montane forests $(100-1,000 \mathrm{~m})$ in Venezuela, Guyana, and Suriname. In Brazil, it occurs at the edges of campina (in the eastern Amazon, Pará State) and in savanna vegetation, specifically in montane fields in the Serra Aracá Mountains (in the western Amazon, Amazonas State). Myrcia albidotomentosa has its distribution restricted to the Amazonian Biome, occurring in grasslands in the states of Pará and Amazonas; there are very few specimens in herbaria in the Brazilian Amazon. Its recognition is facilitated by having leaf blades with acute to acuminate apices, translucent glands in the form of nigrescent dots, tenuous inter-secondary ribs, and flowers with albescent and tomentose induments, making it distinct from other representatives of the genus in the Amazon region. Resembles M. pyrifolia (Desv. ex Ham.) Nied. and M. tomentosa (Aubl.) DC. by having albescent-tomentose induments on its vegetative and reproductive structures, but is quite distinct by having a 4-merous calyx, with sepals of similar dimensions, and a pilous disk zone between the filaments (vs. calyx (4)-5-merous, sepals in two sets, 3-4 larger, 1-2 smaller, and disk zone completely pilous in $M$. pyrifolia; and 5-merous calyx and glabrous disk zone in M. tomentosa).

Specimens examined: BRAZIL. PARÁ: Colares, 18.VIII.1913, fl., A. Ducke s.n. (MG 12671). AMAZONAS: hillside of the Serra Aracá, 04.II.1978, bot., N.A. Rosa \& S.B. Lira 2371 (INPA, MG, NY).

\section{Myrcia amapensis Mc Vaugh, Mem. New York Bot.} Gard. 18(2): 80. 1969.

(Figs. 2 C, D)

Until recently, Myrcia amapensis was considered endemic to Brazil, being restricted to Amapá State (Sobral et al. 2012). In the present study, however, it is recorded from Pará State, where it occurs in campinarana (sandy plains with dense shrubby and arboreal vegetation), secondary forests and mainland savanna, together with predominant species of Cyperaceae, Poaceae, and other fire resistant plants. This species can be easily confused with M. saxatilis (Amshoff) McVaugh when sterile due to its tiny leaf blades (up to ca. $3.5 \mathrm{~cm}$ long) and the absence of indument. However, it can be distinguished mainly by having inflorescences in panicles and calyx 5-merous, with quincuncial pre-flowering (vs. unifloral inflorescences or dyads, and calyx 4-merous, with valvate pre-flowering in M. saxatilis). It is popularly known in the Amazon region 


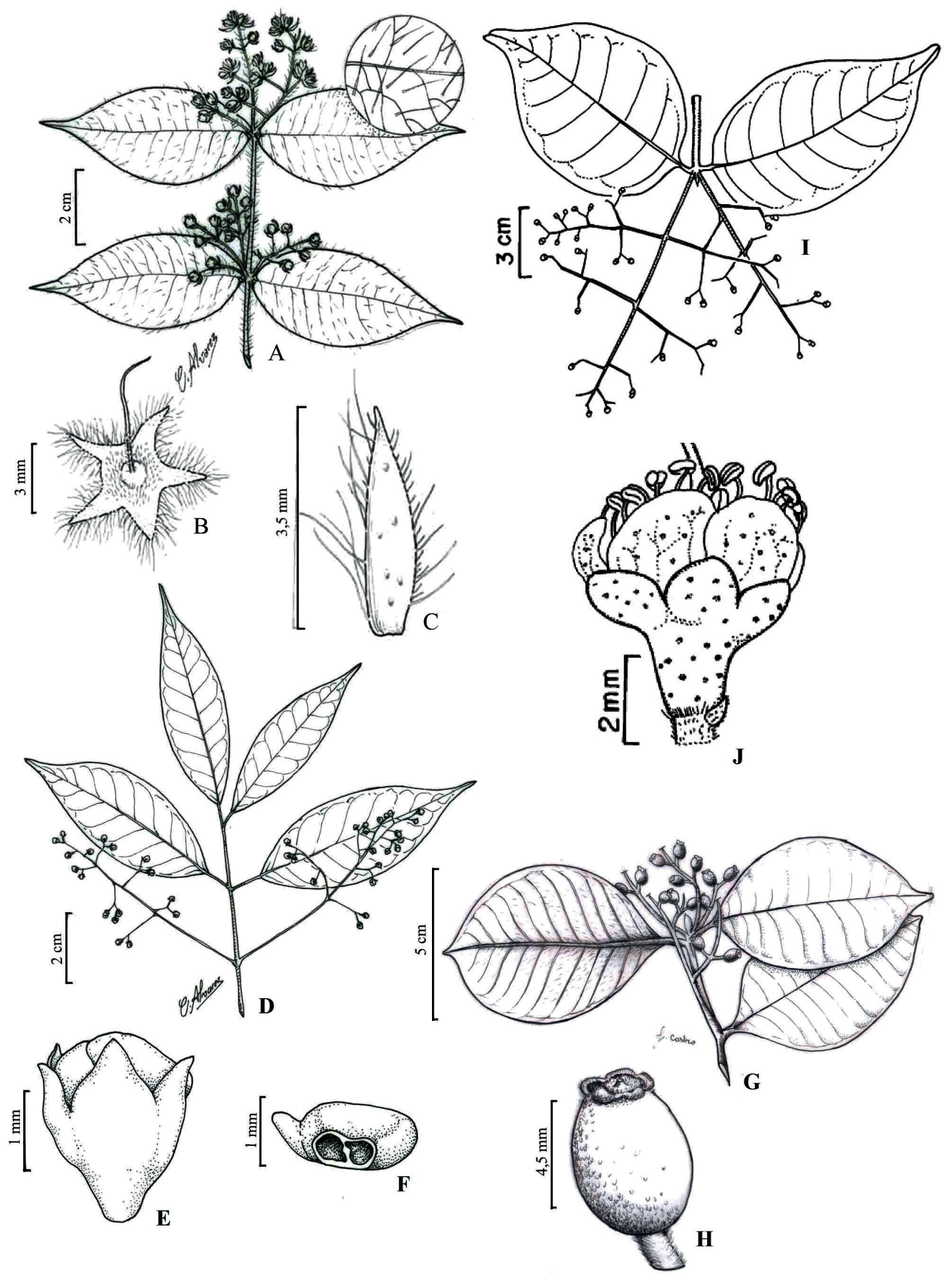

Figs. 1 A-J. A-C. Myrcia huallagae. A. Flowering branch; B. Flower, front view; C. Bract, showing adaxial side. D-F. Myrcia laruotteana. D. Flowering branch; E. Flower bud, showing calyx with valvate pre-flowering; F. Ovary 2-locular, cross-section. G, H. Myrcia mansoniana. G. Fruiting branch; H. Fruit, lateral view. I, J. Myrcia ovata. I. Flowering branch; J. Flower, showing valvate pre-flowering. (A-C. D. Mitja \& D.C. Carvalho 10123; D-F. F. Lima s.n. (MG 10752); G, H. G.T. Prance et al. 24882; I, J. A.S. Rosário 01 \& L.C.B. Lobato). 

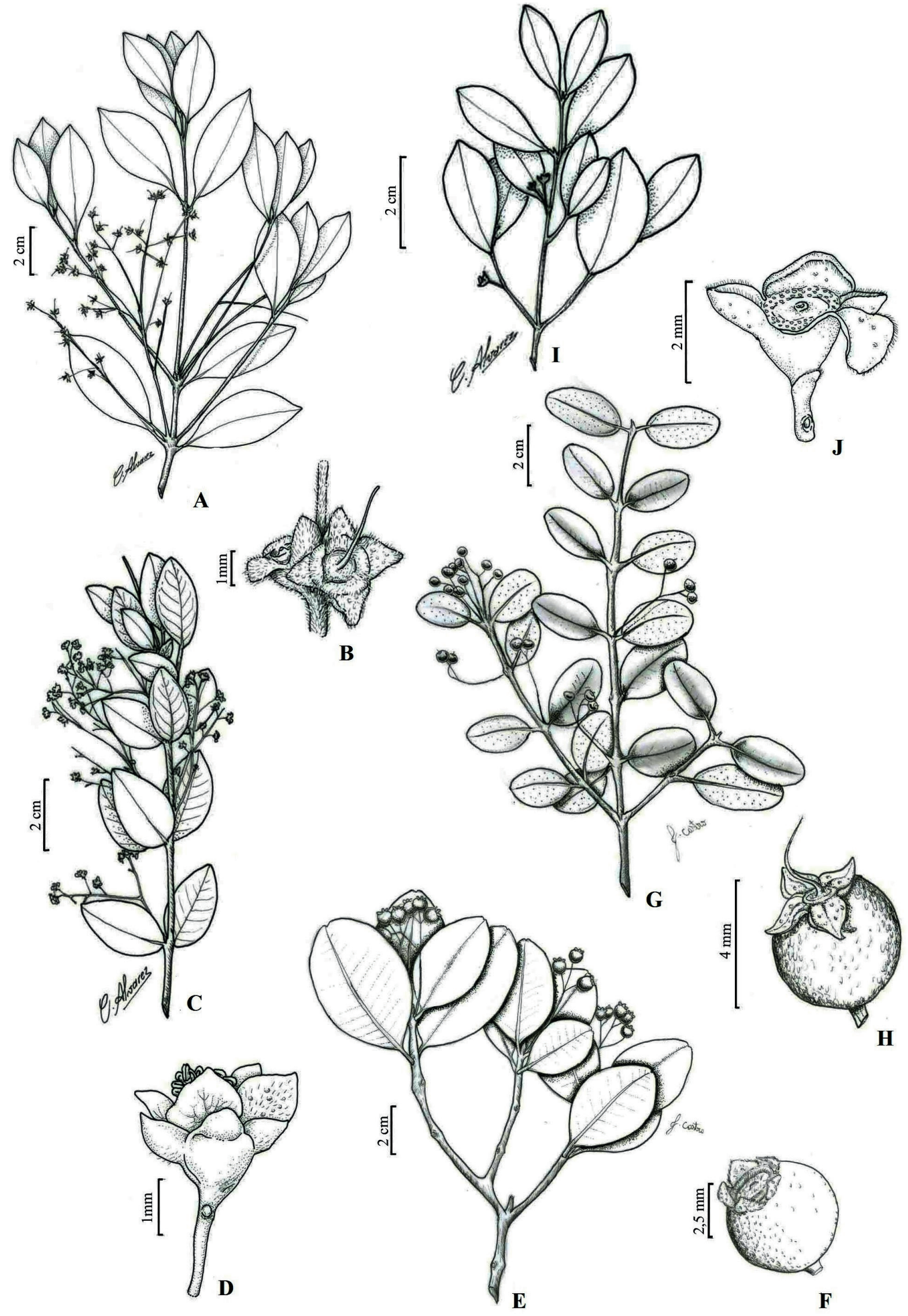

Figs. 2 A-J. A, B. Myrcia albidotomentosa. A. Flowering branch; B. Flower, front view. C, D. Myrcia amapensis. C. Flowering branch; D. Flower, lateral view. E, F. Myrcia clusiifolia. E. Fruiting branch; F. Fruit. G, H. Myrcia revolutifolia. G. Fruiting branch; H. Fruit, lateral view. I, J. Myrcia saxatilis. I. Flowering branch; J. Flower, lateral view (A, B. A. Ducke s.n. (MG 12671); C, D. J.M. Pires et al. s.n. (MG 123182); E, F. N.A. Rosa 251; G, H. R. Lisboa et al. 6666; I, J. L.C.B. Lobato et al. 3794). 
as "murta de pajé" (witchdoctor's myrtle, in Portuguese). Specimens examined: BRAZIL. PARÁ: Sete Varas in Curuá River, 0095'S, 5492’W, 4.VIII.1981, fl., fr., J.J. Strudwick \& G.L. Sobel 4013 (MG); Almeirim, Monte Dourado, MTD-Oeste Road, 22.VIII.1985, fl., J.M. Pires et al. s.n. (MG 123182); Almeirim, Monte Dourado, Água Azul area, near the glebe of Angelim da Reserva Genética, 17.IX.1986, fl., J.M. Pires \& N.T. Silva s.n. (MG 123480).

Myrcia clusiifolia (Kunth) DC., Prodr. 3: 245. 1828. (Figs. 2 E, F)

Based on McVaugh (1969), this species is endemic to the Amazon region, occurring in Venezuela and Brazil. According to Sobral et al. (2012), M. clusiifolia can be found in the states of Amapá and Amazonas. It is recorded here for the first time, however, for Pará State, from a single collection made in a campina environment. It can be inferred, based on the specimens analyzed and Rosário (2012), that the center of distribution of M. clusiifolia in the Brazilian Amazon corresponds to Amazonas State. When sterile, $M$. clusiifolia may be confused with $M$. marginata O.Berg, mainly by having oval leaf blades, markedly coriaceous, with cuneate to slightly obtuse bases and an obtuse to retuse apex. However, M. clusiifolia distinguishes itself by having glabrous leaves and rachis inflorescence 4-7 cm long and glabrous (vs. pubescent leaves and rachis inflorescence greater than $10 \mathrm{~cm}$ long in $M$. marginata). This species shows morphological variations in the pilosity of its petioles. While the specimen from Pará has a pubescent indument coating the entire structure, the samples from Amazonas State have a glabrous petiole or rarely with pubescent trichomes, these being sparse, however, and restricted to the canaliculated region on the adaxial face.

Specimens examined: BRAZIL. PARÁ: Sub-Base Marapí, margin of the Marapí River, 00³7'01'N, 5558'00'W, 21.X.1974, fr., N.A. Rosa 251 (IAN, RB). AMAZONAS: Manaus, Tarumã River, 23.VIII.1949, fl., R.L. Fróes 25103 (IAN); Itaubal, Aracá River, 26.X.1952, R.L. Fróes 29123 (IAN, MICH); Manaus-Caracaraí road, km 130, 25.V.1974, fl., W.A. Rodrigues et al. 9301 (INPA, $\mathrm{RB}$ ); surroundings of Serra Aracá, 25.II.1977, bot., N.A. Rosa \& M.R. Cordeiro 1653 (INPA, MG); Serra Aracá, 0049'N, 6319'W, 06.II.1984, fr., G.T. Prance et al. 28826 (INPA, NY, RB); Barcelos, 0052'29'S, 6320'29'W, 20.VIII.2011, fl., G. Martinelli et al. 17113 (RB).

Myrcia revolutifolia McVaugh, Mem. New York Bot. Gard. 18(2): 121. 1969.

(Figs. 2 G, H)

This species is recorded here for the first time for Pará State, where it occurs in campina environments (sandy plain shrubby vegetation). According to McVaugh (1969), $M$. revolutifolia has restricted distribution in mountainous regions of Venezuela (Amazon region) called "Cerro
Coro-Coro" and "Cerro Duida", at altitudes from 1,200 to $2,300 \mathrm{~m}$. In spite of recognizing their morphological affinities and their similar areas of occurrence, this author considered $M$. planifolia McVaugh and M. revolutifolia to be autonomous species and placed them in the section Aulomyrcia (O.Berg) Griseb. Holst (2002) considered these species to be synonymous, which was not ratified by the present study, as $M$. revolutifolia can be distinguished from M. planifolia by the latter having pubescent inflorescences (vs. glabrous in $M$. revolutifolia) and revolute leaves (vs. flat), in addition to occurring in "Cerro Duida" and "Cerro Coro-Coro (vs."Sipapo"). Based on Prance (1982), the areas of occurrence of these species correspond to the Imerí center of endemism (refuge), which is made up of very old geological formations covering the far north of Brazil (the states of Roraima and Amazonas) to Colombia and Venezuela. The Lisboa et al. 6666 collection represents the first and only record of $M$. revolutifolia for the Brazilian Amazon, being restricted to a campina formation that coincides with the Tapajós-Xingu center of endemism. The existence, so far, of only one specimen of $M$. revolutifolia in herbarium collections reinforces the rarity of this taxon in the Amazon biome. This species can be identified in the field by its aromatic leaves, as described on the label of the specimen analyzed, a feature not observed or recorded in the collections of $M$. planifolia that were analyzed (Rosário 2012).

Specimens examined: BRAZIL. PARÁ: Itaituba, São Luiz do Tapajós, campo dos perdidos, campina, 04²6'4.7'S, $56^{\circ} 03^{\prime} 0.2^{\prime \prime} \mathrm{W}, 20 . X I .1999$, fr., R. Lisboa et al. 6666 (MG).

Myrcia saxatilis (Amshoff) Mc Vaugh, Mem. New York Bot. Gard. 18(2): 105. 1969.

(Figs. 2 I, J)

Species with distribution in Suriname, French Guiana, and Brazil (McVaugh 1969, Rosário 2012). According to Sobral et al. (2012), M. saxatilis is endemic to the Amazon region, occurring in the states of Amapá and Amazonas, in campinarana and savanna vegetation. It is reported here for the first time for Pará State, where it is found in montane environments growing among canga (iron concretions) vegetation. Myrcia saxatilis resembles $M$. amapensis, but is easily distinguished as noted above.

Specimen examined: BRAZIL. PARÁ: Parauapebas, Serra dos Carajás, plateau N4, 12.I.2010, fl., L.C.B. Lobato et al. 3794 (MG).

\section{ACKNOWLEDGMENTS}

The authors are grateful to the Instituto de Pesquisas Jardim Botânico in Rio de Janeiro for their support for the project focusing on Myrciinae in Pará State; to the Museu Paraense Emílio Goeldi for providing the necessary infrastructure for our studies of the Myrtaceae of the Brazilian Amazon; Dr. Marcelo C. Souza and Dr. Marcos Sobral for their suggestions during the taxonomic study; 
Carlos Alvarez and Joel Castro who drew the illustrations; the Fundação Amazônia de Amparo a Estudos e Pesquisas, for the doctoral scholarship (later replaced by the DTI-1 and EV-B scholarships, from CNPq) awarded to the first author; and Brazilian National Council for Scientific and Technological Development, for the Productivity Fellow awarded to the co-authors.

\section{REFERENCES}

Amshoff, G.J.H. 1948. Myrtaceae. In Plant Explorations in Guiana in 1944, Chiefly to the Tafelberg and the Kaieteur Plateau-V (B. Maguire \& Coll., eds.). Bulletin of the Torrey Botanical Club 75(5):528-538.

Barroso, G.M., Peixoto, A.L., Ichaso, C.L.F., Costa, C.G., Guimarães, E.F. \& Lima, H.C. 1984. Sistemática de Angiospermas do Brasil. Universidade Federal de Viçosa, Minas Gerais. 377 p.

Barroso, G.M., Morim, M.P., Peixoto, A.L. \& Ichaso, C.L.F. 1999. Frutos e Sementes: Morfologia aplicada à sistemática de dicotiledôneas. Universidade Federal de Viçosa, Minas Gerais. 443 p.

Brummitt, R.K. \& Powell, C. 1992. Authors of plants names. Royal Botanical Garden, Kew, London. 732 p.

Holst, B.K. 2002. New Species and Notes on Myrtaceae from northern South America. Selbyana 23:137-180.

Holst, B.K., Landrum, L. \& Grifo, F. 2003. Myrtaceae. In Flora of the Venezuelan Guayana (J.A. Steyermark, P.E. Berry, K. Yatskievych, B.K. Holst, eds.). Botanical Garden Press, St. Louis, v. 7, p. 1-99.

Kawasaki, M.L. 1989. Flora da Serra do Cipó, Minas Gerais: Myrtaceae. Boletim Botânica 11:121-170.

Legrand, C.D. \& Klein, R.M. 1969. Myrtáceas. In Flora Ilustrada Catarinense (P.R. Reitz, ed.). Herbário Barbosa Rodrigues, Itajá, p. 219-326.

Lucas, E.J., Belsham, S.R., Nic Lughadha, E.M., Orlovich, D.A., Sakuragui, C.M., Chase, M.W. \& Wilson, P.G. 2005. Phylogenetic patterns in the flesh-fruited Myrtaceae - preliminary molecular evidence. Plant Systematics and Evolution 251: 35-51.

Lucas, E.J., Harris, S.A., Mazine, F.F., Belsham, S.R., Nic Lughadha, E.M., Telford, A., Gasson, P.E. \& Chase, M.W. 2007. Suprageneric phylogenetics of Myrteae, the generically richest tribe in Myrtaceae (Myrtales). Taxon 56:1105-1128.

Lucas, E.J., Matsumoto, K, Harris, S.A., Nic Lughadha, E.M., Benardini, B, \& Chase, M.W. 2011. Phylogenetics, Morphology, and Evolution of the Large Genus Myrcia s.l. (Myrtaceae). International Journal of Plant Sciences 172(7):915-934.

McVaugh, R. 1956. Tropical American Myrtaceae. Notes on generic concepts and descriptions of previously unrecognized species. Fieldiana, Botany 29:145-228.

1958. Myrtaceae (Calyptranthes and Marlierea). In The botany of the Guyana highland - part III (B. Maguire \& J.J. Wurdack, eds.). Memoirs of The New York Botanical Garden 10(1):61-91.

1968. The genera of American Myrtaceae: an interim report. Taxon 17(4): 354-418.
1969. Myrtaceae. In The botany of the Guyana highland - part VIII. (B. Maguire and Coll., eds.). Memoirs of The New York Botanical Garden 18(2):55-286.

Nic Lughadha, E. 1995. Myrtaceae. In Flora do Pico das Almas (B.L. Stannard, ed.): Chapada Diamantina - Bahia, Brasil. Royal Botanic Gardens, Kew, London, p. 492-517

Prance, G.T. 1982. Forest refuges: Evidence from woody angiosperms. In Biological Diversification in the Tropics (G.T. Prance, ed.). Columbia University. Press, New York, p. 137-156

Pires, J.M. \& Prance, G.T. 1985. The vegetation types on the Brazilian Amazon. In Key environments: Amazonia (G.T. Prance \& T.E. Lovejoy, eds.). Pergamon Press, Oxford, p. 109-145

Radford, A.E., Dickison, W.C., Massey, J.R. \& Bell, C.R. 1974. Vascular Plant Systematics. Harper \& Row, Publishers, New York. 891 p.

Rosário, A.S. 2012. Subtribo Myrciinae (Myrtaceae) na Amazônia brasileira, com ênfase no Estado do Pará, Brasil. Tese 300 f., Escola Nacional de Botânica Tropical / Instituto de Pesquisas Jardim Botânico do Rio de Janeiro, Rio de Janeiro.

Rosário, A.S., Baumgratz, J.F.A. \& Secco, R.S. 2014a. Contribuição à taxonomia de Marlierea (Myrciinae; Myrtaceae) no Brasil. Rodriguésia 65(1): 245-250.

2014b. Taxonomic notes in Calyptranthes (Myrciinae; Myrtaceae) in the Brazilian Amazon. Phytotaxa 186(3):158-165.

Rosário, A.S., Secco, R.S., Amaral, D.D., Santos, J.U.M. \& Bastos, M.N.C. 2005. Flórula Fanerogâmica das Restingas do Estado do Pará. Ilha de Algodoal e Maiandeua. 2. Myrtaceae A. L. de Jussieu. Boletim Museu de Ciências Naturais Paraense Emílio Goeldi 1(3):31-48.

Rosário, A.S. \& Secco, R.S. 2006. Sinopse das espécies de Marlierea Cambess. (Myrtaceae) na Amazônia brasileira. Acta Amazonica 36(1):521-535.

2013. Contribuição à taxonomia das Myrtaceae da Floresta Nacional de Caxiuanã. In Caxiuanã: paraíso ainda preservado IV ed. (P.L.B. Lisboa, ed.). Museu Paraense Emílio Goeldi, p. 219-230

Sobral, M. 2003. A família das Myrtaceae no Rio Grande do Sul. Editora Unisinos, São Leopoldo, Rio Grande do Sul. 215 p.

Sobral, M., Proença, C., Souza, M., Mazine, F. \& Lucas, E. 2012. Myrtaceae. In Lista de Espécies da Flora do Brasil. Jardim Botânico do Rio de Janeiro. Available at: <http://floradobrasil.jbrj.gov.br/2012/ FB000171>. Acessed on: 15.08.2012.

Souza, M.A.D., Kawasaki, M.L. \& Holst, B.K. 1999. Myrtaceae. In Flora da Reserva Ducke: guia de identificação das plantas vasculares de uma floresta de terra-firme na Amazônia Central:. INPA, Manaus. p. $417-436$

Souza, M.C., Morim, M.P., Conde, M.M.S. \& Menezes, L.F.T. 2007. Subtribo Myrciinae O.Berg (Myrtaceae) na Restinga da Marambaia, RJ, Brasil. Acta Botanica Brasilica 21(1):49-63.

Thiers, B. 2012 [continuously updated]. Index Herbariorum: A global directory of public herbaria and associated staff. New York Botanical Garden's Virtual Herbarium. Available at: $<$ http://sweetgum.nybg. org/ih $>$. Acessed on 14, August, 2012.

Wilson, P.G. 2011. Myrtaceae. In The Families and Genera of Vascular Plants (K. Kubitzki, ed.). Springer-Verlag, Berlin Heidelberg, v. 10 , p. $212-271$

Wilson, P.G., O’Brien, M.M., Heslewood, M.M. \& Quinn, C.J. 2005. Relationships within Myrtaceae sensu lato based on a matK phylogeny. Plant Systematics and Evolution 251:3-19. 